Mehmet Muharrem Erol

Hüseyin Melek

Nermin Kelebek Girgin

Ahmet Sami Bayram

\title{
Rijit Bronkoskopiyle Sicak Serum Fizyolojik Uygulaması
}

\author{
Application of Rigid Broncoscopy with \\ Heated Serum Physiologic
}

Geliş Tarihi/Received: 07.08.2012

Kabul Tarihi/Accepted: 12.10.2012

Türk Yoğun Bakım Derneği Dergisi, Galenos Yayınevi tarafından basılmıștır.

Journal of the Turkish Society of Intensive Care, published by Galenos Publishing.

ISNN: 1300-5804

Mehmet Muharrem Erol (凶), Hüseyin Melek,

Ahmet Sami Bayram

Uludağ Üniversitesi Tıp Fakültesi, Göğüs Cerrahisi

Anabilim Dalı, Bursa, Türkiye

Nermin Kelebek Girgin

Uludağ Üniversitesi Tıp Fakültesi, Anesteziyoloji ve

Reanimasyon Anabilim Dalı, Bursa, Türkiye

E-posta: muharremerol@hotmail.com

Tel.: +902242952340

ÖZET Rijit bronkoskopi (RB), göğüs cerrahisi rutininde oldukça sık uygulanan bir işlemdir. Yabancı cisim aspirasyonları, atelektazilerin açılması, hemoptizinin kontrolü ve tanısal amaçlı kullanım başlıca uygulama alanlarıdır. Bronkoskopi işleminde irrigasyon amacıyla soğuk Serum Fizyolojik (SF) uygulanır. Bu yazıda atelektaziyi açmak amacıyla, literatürde daha önce hiç uygulanmayan, bronkoskopi sırasında sıcak SF uyguladığımız bir olguyu sunduk.

Anahtar Kelimeler: Serum fizyolojik, bronkoskopi, hemoraji
SUMMARY Rigid bronchoscopy (RB) is a procedure commonly performed thoracic surgery is quite routine. The main application areas of bronchoscopy; foreign body aspiration, atelectasis, control of hemoptysis and diagnostic procedures. In bronchoscopy, cold Serum Physiologic (SP) is used for irrigation. In this article, we present a case used warm SP in order to open an atelectasis during broncoscopy that have never been used in the literature.

Key Words: Serum physiologic, bronchoscopy, hemorrhage

\section{Giriş}

Bronkoskopi, trakeobronşial ağacın endoskopik olarak değerlendirilmesi olup, fleksibl ya da rijit fiberoptik aletlerle uygulanabilmektedir. Başlıca endikasyonları arasında yabancı cisim aspirasyonları, trakeal ve/veya bronşial stent yerleştirilmesi ve fistül tedavisi, atelektazi açılması, masif hemoptizi tedavisi ve trakea-bronşial ağaçtaki kurutların temizlenmesi sayılabilir (1-3).

Bronkoskopi içinden rutin uygulamalarda irrigasyon amacıyla soğuk ya da oda sıcaklığında Serum Fizyolojik (SF) uygulanır. Bu yazıda atelektazi açmak amacıyla literatürde daha önce hiç uygulanmayan sıcak SF uyguladığımız bir olguyu sunduk.

\section{Gereç ve Yöntem}

Otuz bir yaşında kadın olgu pnömoni, akut renal yetmezlik ve sepsis tanılarıyla yoğun bakım ünitesine yatırılmış ve tedavi sürecinde cerrahi trakeostomi açılmıştı. Trakeostomiden 7 gün sonra spontan solunumu kötüleşen ve fizik muayenesinde sol hemitoraksta solunum sesleri alınmayan olgunun akciğer grafisinde sol akciğerde total atelektazi izlendi (Resim 1). Atelektaziyi açmak amacıyla fleksibl bronkoskopi (FB) yapıldı, trakeostomi insizyonundan sızıntı tarzında kanama saptandı. Işlem sonrası çekilen kontrol akciğer grafisinde sol total atelektazinin devam etmesi üzerine rijit bronkoskopi $(R B)$ uygulandı. Rijid bronkoskopi sırasında trakeobronşial ağaç soğuk SF ile yıkandı. Ancak sol ana bronşu tıkayan hemorajik 
kurutlar nedeniyle atelektazi açılamadı. Bir gün sonra FB işlemi tekrarlandı, fakat yine sonuç alınamadı. Olguya ikinci kez RB uygulandı, sol ana bronş girişini tıkayan hemorajik kurutların devam ettiği gözlendi, trakeobronşial ağaç soğuk SF ile yeniden yıkandı. Işlem sonrası akciğer grafisinde atelektazi devam etmekte idi. Olguda FB işlemi tekrarlandı. Ancak bu işlemde de kurutlar temizlenemedi, atelektazik akciğer açılmadı. Üçüncü kez RB yapıldı. Bu işlem sırasında pıntıları çözmek amacıyla 50 Co'de ısıtılmış SF, 10 cc'lik enjektör yardımıyla trakeobronşial ağaca irrigasyon yapıldı. Toplam $100 \mathrm{~mL}$ ısıtılmış SF kullanıldı. Isıtılmış SF'in hemorajik kurutları çözmesi nedeniyle sol ana bronş içindeki pıhtılar rahatıkla aspire edildi. Işlem sırasında hemodinamik parametrelerde herhangi olumsuz bir değişiklik oluşmadı. Bronkoskopi sonrası hastanın akciğer grafisinde tüm akciğer alanları tam açıktı ve atelektazı

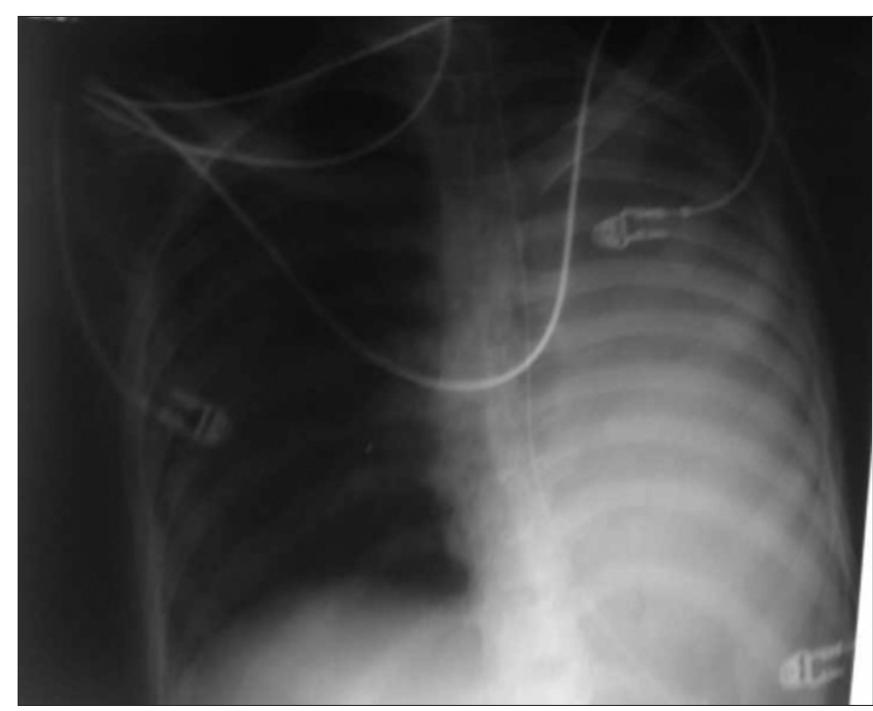

Resim 1. Total atelektazi

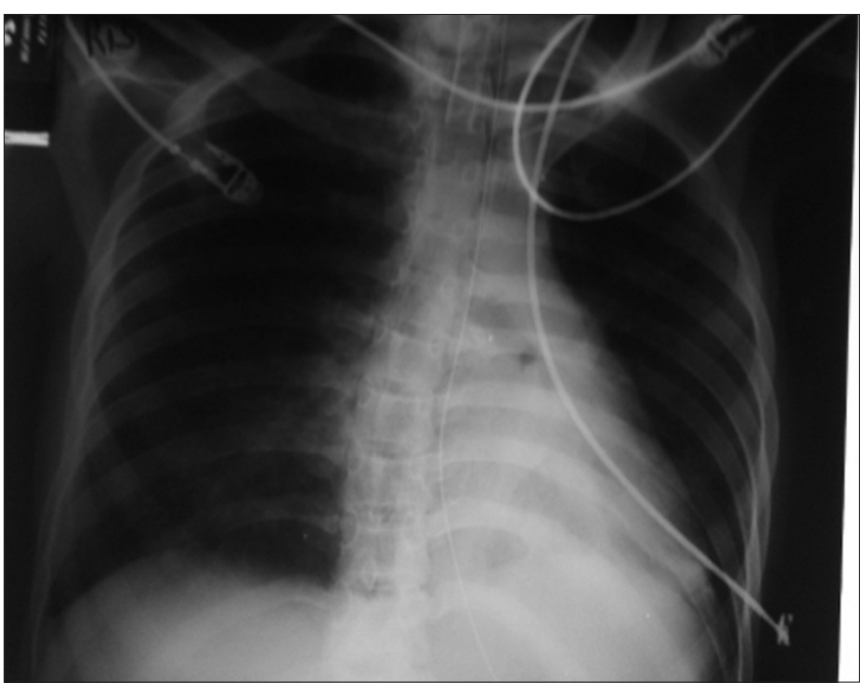

Resim 2. Ateletazi açılmış ile uyumlu imaj kalmamıştı (Resim 2). Olgunun işlem sonrasında da sıcak SF uygulanımına bağlı solunumsal ve hemodinamik parametrelerinde olumsuz değișiklikler saptanmadı.

\section{Tartışma}

Göğüs hastalıkları ve göğüs cerrahisi uygulamalarında yaygın olarak kullanılan bronkoskopi, havayollarının görülmesi, alt havayollarından örnek alınması ve değişik incelemelerin yapılmasına olanak sağlar (4). Fleksibl ya da rijit bronkoskopi işlemi yoğun bakım ünitelerinde tedavi edilmekte olan olgularda trakea ya da bronşa stent yerleştirilmesi, trakea-bronşial ağaçtaki kurutların temizlenerek atelektazilerin açılması ya da hemoptizi tedavisi amacı ile sık uygulanmaktadır $(4,5)$.

Rutin bronkoskopik incelemeler oldukça güvenli olmasına rağmen yoğun bakım hastalarında daha fazla komplikasyon riski vardır. Hipoksi, hiperkapni, laringospazm, bronkospazm, kanama, vazovagal refleks, kardiyak aritmi, intrakraniyal hipertansiyon, ateş ve pnömoni başlıca karşılaşılabilecek sorunlar arasındadır $(3,5)$. Bu olguda bronkoskopi işlemleri total intravenöz genel anestezi altında gerçekleştirildi ve bu komplikasyonlar ile karşış̧ılmadı. Işlem sırasında oksijenasyon ve hemodinamik parametreler normal sınırlarda seyretti.

Bronkoskopi endikasyonları arasında sayılan atelektazi mukus tıkacı, yabancı cisim, kan pıhtısı ya da endobronşial tümöre bağlı gelişebilmektedir. Neden mukus tıkacı olduğunda oda havasındaki SF ile irigasyon yapılarak bronkoskop yardımı ile tıkaç temizlenmektedir (3). Ancak bizim olgumuzda tıkaç nedeni kan pıhtısı olup, tekrarlayıcı SF ile yıkama işlemlerine rağmen atelektazi devam etmekte idi.

IsıııImış SF, göğüs cerrahisinde akciğer rezeksiyonları ve diğer torakotomi uygulamalarında toraks boşluğunu yıkamak amacıyla kullanılmaktadır. Bronkoskopik işlemlerde kullanılmayan bu yöntem, bu olguda hemorajik kurut temizleme gibi özel bir endikasyonla uygulanmıştır. Bu uygulama sırasında eğer hemoraji bronşial seviyede olsa idi damar ağızları açılarak kanamanın yeniden başlamasına ve/veya artmasına yol açabilirdi. Ancak daha önce yapılan FB ve RB sırasında sızıntı şeklindeki kanamanın trakeostomi düzeyinden olduğu ve aşağıya doğru akan kan nedeniyle hemorajik kurutlar oluştuğu saptanmıştı. Bu nedenle yeni bir kanama başlaması beklenmedi.

Bu uygulama literatürde ilk defa belirtilmiştir. Bundan sonraki benzer olgularda rutin yapılan bronkoskopi uygulamalarına yanıt alınmadığında, bu yöntemin kolaylık sağlayabileceğini düşünüyoruz. 


\section{Kaynaklar}

1. Wei JL, Holinger LD. Management of foregn body of the airway. In: Shields TW, Locicero III J, Ponn RB, Rusch VW (Eds). General Thoracic Surgery. 6th ed.

Philadelphia: Lippincott Williams-Wilkins, 2005:995-1005.
2. Güngör A. Trakea bronşial yabancı cisimler. Akay H (Ed). Göğüs Cerrahisi. Ankara: Antıp AŞ Yayınları, 2003: 35-42.

3. Flexible Bronchoscopy. Civetta, Taylor, Kirby's Manuel of Critical Care. Gabrielli A, Layon AJ, Yu M (Eds). Philadelphia:

Lippincott Williams\&Wilkins, 2012, 76-82.
4. Çelik G. Bronkoskopi ve bronkoskopik teknikler. Göğüs Cerrahisi. Ökten I, Güngör A (Eds). Ankara: Sim Matbaacılık, 2003; 201-19.

5. Krinzman SJ, Irwin RS. Bronchoscopy. Irwin RS, Rippe JM, Curley FJ, Heard SO (Eds). Büyükkıdan Yelken B (çeviri ed). 3.baskı. Nobel Tıp Kitabevi, 2005; 135-140. 